science in the talks programmes of the B.B.C. is not enough, but in the congested home service schedules, politics, sociology and straight service talks have to compete in a quota above which the listener will not devote attention. At present, "Science Magazine", on the home service every fortnight, and "Science Notebook", in the short-wave overseas service, merit consideration.

Contributions to the discussion came from speakers directly concerned with the scientific and technical Press, films and broadcasting. Among the points made were that scientific men are partly to blame for unsatisfactory reports on scientific matters in the Press because of their dislike of publicity and their attitude to those who try to interpret such matters to the layman. Hence those who can write well should do so. The censorship of scientific news creates a vacuum which tends to fill with unreliable information; rather should the scientific man give an interview and take the reporter into his confidence, but refrain from extensive statements by telephone. The 'pipe-line' connecting the scientific world and the Press is too narrow, scientific information has to pass through several stages of digestion before it is published in the lay Press, and newspaper editors do not appear to realize the existence of the great public interest in scientific matters. The Press should have scientific editors, who should have a wide knowledge of the sciences and adequate contacts to enable them to check scientific news; they should be able to rely on the professional and learned societies for aid. A 1951 Exhibition, already mooted, should be supported by the professional institutes of the sciences. Historical and biographical films of sciences and scientific men should be encouraged; the Ministry of Education and the learned and professional scientific bodies could assist in these productions. The success of "Science Magazine" depends upon the scientific men who write the scripts; only one idea at a time should be transmitted, in a concise manner.

It was suggested by several speakers that groups in local sections of professional bodios, or an informal society or group for people interested in the publicity of science, should be formed to further, by exchange of ideas and experiences, the presentation of science to the public.

\section{ANTHROPOLOGY IN PORTUGAL}

$\mathrm{T}$ history of any branch of science is a very intricate affair as it entails national and international claims of priority, and one is at a loss as to whether the contribution of a particular school is of greater or less significance. The problem is still further complicated when the protagonists are still alive. The history of anthropology in Portugal is worthy of notice by itself, if only because Portugal was one of the great colonial Powers whose influence can still be felt in Brazil, Africa, India and the East Indies.

Pereira da Costa, Carlos Ribeiro and Nery Delgado founded a Geological Society in Lisbon in 1857. In 1865 Pereira da Costa published his "Notices on Human Skeletons discovered in a Cave by Arruda". In 1885, a Ministerial decree authorized the reorganization of museums, and the director asked Barros da Cunha to examine some Timor skulls deposited there. The museum was divided into sections of botany, zoology, geology and mineralogy, anthropology and archæology, each with its own director.
From this time dates the systematic collection of materials from the Portuguese Colonies.

On July 2, 1885, Dom Luiz passed a further decree creating a Department of Anthropology, Human Palæontology and Archæology in the Faculty of Philosophy of the University of Coimbra. Two years previously, Bernard Machado had brought up a Bill creating Departments of Agriculture, Rural Economy, Mines and Zootechnology in the University.

In the earlier phase emphasis was laid on prehistoric archxology, particularly on the existence of tertiary man in Portugal, because of the interest shown in the discovery of da Arruda in the grottoes of Furninha and Cesareda, and the graveyards of the Tejo Valley. In the second phase physical anthropology came to the fore, partly owing to the zeal of Ferraz de Macedo and Arruda Furtado. Macedo began his craniometric studies on the remains found in the old cemeteries of Lisbon in 1882 ; and in the following years he devoted himself to criminal anthropometry with good results. The methods standardized by him have proved useful to subsequent workers in this field.

The first professor of anthropology at the University of Coimbra was Henrique Texeira Bastos, who divided the subject into : (1) zoological and general anthropology and (2) prehistoric archæology. Section I dealt with the osteology and craniometry of primates and physiological differences between them and man. The position of man among the primates was also treated. In osteology, the comparative osteology of man was studied. In this section were included methodology, anthropometry, statistics, etc. Section 2 treated the comparative history of man and human races, cultural anthropology, linguistics and prehistoric archæology. The Faculty of Letters taught ethnology for a semester to those who were graduating in geography, but as a matter of fact the subject received but scant attention.

In 1911, Prof. Barros da Cunha began a free voluntary course on colonial anthropology at the Institute of Anthropology and at the Colonial Museum, the subjects being customs, religion, dress, art, folklore and languages. Soon after, monographs on places of local interest began to be published in the Transactions of the Section of Anthropology of the University of Coimbra.

Bastos was succeeded by Bernard Machado, whose enthusiasm and interest in physical anthropology ushered in a new period of intense activity. The series of monographs published in the Transactions attest his powers of classification and his unusual activities in all branches of science. 'But Machedo's work could not properly come under orthodox anthropology; for one thing, his treatment was too diffuse; and for another, he was interested in too many things at the same time.

Two other names stand out in Portuguese anthropology, namely, Anthony da Costa Ferreira and Ferraz Macedo. The latter may be claimed as the true founder of physical anthropology in Portugal, for his craniometric investigations provided a basis for later workers.

With the reform of the University of Coimbra in 1911, two institutes of anthropology were established, one at Oporto and the other at Lisbon. At the same time, at Coimbra the curriculum was reorganized and anthropology was divided into physical and cultural. The influence of social and climatic factors was actively studied and attention was directed to palæontology; and as an ultimate 
objective, the integration of anthropological and genetic data was envisaged as a general science under natural science.

Genealogical and statistical methods were devised to help craniology and sociology. Since 1907 the Institute has acquired more than 5,000 volumes and 100,000 index cards of measurements.

The Institute at Coimbra has, under Prof. Eusebio Tamagnini, turned out a group of young and active workers in the field of physical anthropolngy. The names of J. Serra, A. Lopes, A. Themido, W. L. Stevens and de Morais are familiar to workers in Europe and America. The output of original work produced during the War gives promise of greater things to come.

R. E. G. Armatton.

\section{FORTHCOMING EVENTS}

\section{Monday, January 28}

ROYal SocIETY of ARTS (at John Adam Street, Adelphi, Isondon, W.C.2), at 1.45 p.m.--Dr. S. G. Hooker: "High Speed Flight" (Cantor Lectures, 2).

Institution of Electrical ENGINEERS (at Savoy Place, Victoria mbankment, London, W.C.2), at 5.30 p.m.-Discussion on "Electrical Aids to Coal Production" (to be opened by Mr. R. Crawford).

ROYAL GEOGRAPHICAL SOCIETY (at Kensington Gore, London S.W.7), at 5.30 p.m.-Mr. F. R. Newens: "In Northern Waters" (kodachrome films of Iceland, Norway and Denmark, with Com mentary).

CHFMICAL SOCIETY (joint meeting with SWANSEA UNIVERSITY COLLEGE CHEMICAI SOCIETY, in the Chemistry Lecture Theatre, University College, Swansea), at 6 p.m.-Prof. J. Kendall, F.R.S. "The Separation of Isotopes and Thermal Diffusion".

association of Austrian Engrneers, Chemists aND Scientific WORKERS IN GREAT BRITAIN (at the Austrian Centre, 69 Greencroft
Gardens, London, N.W.6), at 7.15 p.m.-Dr. W. Saraga : "Electric Gardens, London, N.W.6), at 7.15 p.m.-Dr. W.
Networks, some Aspects of General Interest".

\section{Tuesday, January 29}

Royal Statistical Societr (at the London School of Hygiene RoYs and Tropical Medicine, Keppel Stree,

ROYAL ANTHROPOLOGICAL INSTITUTE (at 21 Bedford Square, London W.C.1), at 5.30 p.m.-Dr. Oliver Garrod : "An Account of the Kashga Tribe of Fars"

BRITISH INSTITUTION OF RADIO ENGINERR, LONDON SECTION (at the Institution of Structural Engineers, 11 Upper Belgrave Street, London, S.W.1), at 6.15 p.m.-Mr. R. Spears : "Gold Film Electrodes for High Frequency Quartz Plates".

BRITISH INSTITUTION OF RADIO ENGINEERS, NORTH-WESTERN Section (in the Reynolds Hall, College of Technology, Sackville Street, Manchester), at 6.45 p.m.-Flight-Lieut. C. Bovill: "Aircraft Radio".

INSTITUTION OF ELECTRICAX ENGINEERS, LONDON STUDENTS' SECTION (at Savoy Place, Victoria Embankment, London, W.C.2), at 7 p.m.- Problems Night.

\section{Wednesday, January 30}

ROYAI, SocIETY of ARTS (at John Adam Street, Adelphi, London, W.C.2), at 1.45 p.m.-Mr. Kenneth Holmes: "The Place of the Art School in the Iife of the Community".

PHYSICAI SOCIETY, CoLOUR GRoUP (in the small Physics Lecture Theatre, Imperial College, Imperial Institute Road, London, S.W.7), at 3.30 p.m.-Mr. R. Donaldson: "A Colorimeter with Six Matching Spectrophotometer".

INSTITUTION OF ELECTRICAL ENGINEERS, RADIo SECTION (at Savoy Place, Victoria Embankment, London, W.C.2), at 5.30 p.m. - Mr D. I. Lawson, Mr. A. V. Lord and Mr. S. R. Kharbanda: "A.Method of Transmitting Sound on the Vision-Carrier of a Television System".

INSTITUTE OF WELDING (at the Institution of Civil Engineers, Great George Street, London, S.W.1), at 6 p.m.--Capt. R. B. Croft and Capt. O. Lithgow: "Mobile Welding with the Royal Engineers".

Thursday, January 31

QUEAN MARY COLLEGE (in the Hatton Lecture Theatre, Queen Mary College, Mile End Road, London, E.1), at 4.30 p.m.-Prof. Edmund Giffen: "Engineering Research in the University" (Inaugural Lecture) Association For ScIENTIFIC PHOTOGRAPHY (at the Caxton Hall, "Forensic Photography".

\section{Friday, February I}

SOCIETx FOR VISITING ScIENTISTS (at 5 Old Burlington Street, London, W.1), at 7.30 p.m.-Discussion on "Science in Czechoslovakia" (Speakers: Prof. J. Beren).

\section{APPOINTMENTS VACANT}

Applicatrons are invited for the following appointments on of before the dates mentioned:

LECTURER IN PHYSICS-The Principal, Huddersfleld Technical College, Huddersfleld (January 31).

TEACHER OF ENGINEERING SUBJECTS-The Principal, Technical School, Oldbury, Wores. (February 2).

LECTURER OR'SENIOR LECTURER (Woman) IN MATHEMATICS, and a LECTURER OR SENIOR LECTURER (WOMan) IN GARDENING, at the Bingley Training College-The Chief Education Officer, County Hall, Wakefield (February 4).

TEACHER (full-time) OF CHEMIsTRY-The Principal, Harris Institute, Preston (February 7).

RESIDENT ENGINEER (temporary), and Assistant RESIDENT ENGINEERS (2, temporary)-The Water Engineer, Liverpool Corporation, 55 Dale Street, Liverpool 2 (February 9).

TEacher (full-time) of Mathematics-The Principal, Enfleld Technical College, Queensway, Enfield, Middx. (February 9).

ASSISTANT DIRECTOR OF EXAMINATIONS (temporary)-The Secretary, Civil Service Commission, 6 Burlington Gardens, London, W.1, endorsed 'A.D.E.' (February 11).

LECTURER IN THE ENGINEERING DEPARTMENT (Graduate well qualifled by industrial and teaching experience to take Electrical Engineering to an advanced standard)-The Registrar, North Gloucestershire Technical College, Cheltenham (February 11).

Principal of the Crumirn Mining and TeOHnical ColuegeThe Director of Education, County Hall, Newport, Mon. (February 11). SENIOR LECTORER IN THE DEPARTMENT OF ELECRICAL ENGINTER ING in the University of Cape Town-The Ministry of Labour and National Service, Appointments Department, A.9, Technics and Scientiflc Register, Room 670, York House, Kingsway, London, W.C.2, quoting D.1683.A (February 12).

EXPERT in the manufacture of Activated Charcoal by the Goverm ment of Ceylon-The Ministry of Labour and National Service, Appointments Department, Technical and Scientific Register, Room (February

HEAd OF THE Pharmacology Department-The Chairman, British Schering Research Laboratories, Ltd., Alderley Edge, Cheshire (February 15).

JoINT ASSISTANT DIRECTOR-The Secretary, Gas Research Board,

1 JoINT ASSISTANT DIRECTOR-The Secretary, Gas

PROFESSOR OF MECHANICAL ENGINEERING at the Military College Professor of Mechancal Civil Service Commission, Burlington Gardens, London, W.1, endorsed 'M.C.S.' (February 18).

Gardens, London, W.1, endorsed 'M.C.S.' (February 18).

ENGINEER AND SURVEYOR-The Clerk to the Neston Urban District
Council, Council Offices, Town Hall, Neston, Wirral (February 28). LECTURER IN INDCSTRIAL HEALTH-The Secretary, University LECTURER IN INDUSTRIAL
Court, Glasgow (February 28).

Court, Glasgow (February 28). MECHANICAL ENGINEERING ASSISTANT-The Secretary, Irish Lights Office, 28 d'Olier Street, Dublin (March 1).

Principal, a Professor of PATHOLOGY, and a Professor or PHYSIOLOGY - The Secretary, Royal (Dick) Veterinary College, Summerhall, Edinburgh 9 (March 15).

PROFEsSOR OF PHYSICS-The Principal, Heriot-Watt College, Edinburgh (April 22).

Professor in Glass Thennology-The Pro. Vice-Chancellor, Benares Hindu University, Benares, India (April 30)

ASSISTANT SUPERINTENDENT at Regent's Park Gardens, and a PATHOLOGIST and PARASITOL GIST-The Secretary, Zoological Society of London, Regent's Park, London, N.W.8 (May 1).

CHEMIST for the Intelligence Section of the Plant and Animal Products Department-The Establishment Officer, Imperial Institute, South Kensington, London, S.W.7.

CHEMIST (Ref. ER/E.216) with industrial experience in the examination and testing of liquid fuels and lubricants, a CHEMIST or PHYSICIST (Ref. ER/E.217) with a bias towards engineering and with industrial experience, and an ASSISTANT CHEMIST (Ref. ER/E.218) for general analytical work-The Staff Officer, London Transport, 55 Broadway, London, S.W.1, quoting the appropriate Ref. No. LECTURER IN BIOLOGY (temporary) in the Cardiff Technical College -The Director of Education, City Hall, Cardiff.

TEA CHER OF ELEOTRICAI ENGINEERING SUBJECTS to Higher National Certificate standard-The Headmaster, Dolcoath Technical School, Camborne, Cornwall.

LECTURER IN MINING-The Clerk to the Governors, Technical College, Infirmary Road, Chesterfleld.

Assistant LeCTURER IN PHYSICS, and a LeCTURER IN MINING, at the Huddersfleld Technical College-The Director of Education, Education Offices, Peel House, Huddersfleld.

\section{REPORTS and other PUBLICATIONS}

(not included in the monthly Books Supplement)

\section{Great Britain and Ireland}

West India Royal Commission. Report on Agriculture, Fisheries, Forestry and Veterinary Matters. By F. L. Engledow. (Cmd. 6608.) Pp. viii +235. (London: H.M. Stationery Office, 1945.) $38.6 \dot{d}$. net.
West India Royal Commission, 1938-39. Statement of Action taken on the Recommendations. (Cmd. 6656.) Pp. 108. (London: H.M. Stationery Office, 1945.) $2 s$. net. Colonial Office. Development and Welfare in the West Indies, 1943-44. Report by Sir Frank Stockdale. (Colonial No. 189.) Pp. iv +115 . (London: H.M. Stationery Office, 1945.) 2s. net. $[1110$ Ministry of Agriculture and Fisheries. Bulletin No. 131 : Winter H.M. Stationery Office, 1945.) $9 d$. net.
[1810 